\title{
Herbert of Cherbury, Descartes and Locke on Innate Ideas and Universal Consent
}

\author{
Mattia Mantovani, KU Leuven \\ mattia.mantovani@kuleuven.be
}

[Penultimate draft. For the published version see Journal of Early Modern Studies 8/1 (2019), pp. 83-115.]

\begin{abstract}
The present paper investigates the seventeenth-century debate on whether the agreement of all human beings upon certain notions - designated as the "common" ones-prove these notions to be innate. It does so by focusing on Descartes' and Locke's rejections of the philosophy of Herbert of Cherbury, one of the most important early modern proponents of this view. The paper opens by considering the strategy used in Herbert's arguments, as well as the difficulties involved in them. It shows that Descartes' 1638 and 1639 reading of Herbert's On Truth — both the 1633 second Latin edition and Mersenne's 1639 translation-was instrumental in shaping Descartes' views on the issue. The arguments of Locke's Essay opposing Herbert's case for innatism are thus revealed to be ineffective against the case which Descartes makes for this same doctrine, since Descartes had in fact framed his conception of innateness in opposition to the very same theses as Locke was arguing against. The paper concludes by explaining how two thinkers as antithetical as Locke and Descartes came to agree on at least one point, and a truly crucial one: namely, that universal consent counts as a criterion neither for innatism nor for truth.
\end{abstract}

Keywords: Herbert of Cherbury, Descartes, Locke, innate ideas, universal consent, common notions

The claim that "that there are certain Principles ... universally agreed upon by all Mankind," and that a universal agreement of this sort can only be explained by the innateness of said principles, dates back at least to Cicero, and was still a quite widely-held position in the early modern age. Leading intellectuals of the Reformation such as Melanchthon and Calvin made use of it to argue for the existence of God. ${ }^{1}$ When Locke claimed, as he did at the beginning of his Essay Concerning Human

\footnotetext{
${ }^{1}$ On the fortune of the argument from Antiquity to the Early Modern Age see Reinhardt G. Kottich, Die Lehre von den angeborenen Ideen seit Herbert von Cherbury, Berlin: Schötz, 1917. Klaus Oehler, "Der Consensus omnium als Kriterium der Wahrheit in der antiken Philosophie und der Patristik: Eine Studie zur Geschichte des Begriffs der Allgemeinen Meinung," Antike und Abendland 10 (1961), pp. 103-129.
} 
Understanding (1689), that "there is nothing more commonly taken for granted" than the existence of some universally-held—and, therefore (it was argued) innate-notions, he was exaggerating only slightly:

It is an established Opinion amongst some Men, that there are in the Understanding certain innate principles; some primary notions, Koเvai हैvvolal, Characters, as it were, stamped upon the Mind of Man, which the Soul receives in its very first Being; and brings into the World with it. ${ }^{2}$

This was especially true for seventeenth-century England. One of the major thinkers of the timeEdward Herbert of Cherbury - had built an entire philosophical system precisely on the doctrine of universal consent, bringing this argument to the very forefront of the philosophical debate. ${ }^{3}$ Locke realized, therefore, that he had to discuss Herbert's main arguments, so well-known to most of his readers, if he was going to succeed in convincing them of the truth of his own views (Herbert is, as a matter of fact, the only philosopher mentioned in the first book of the Essay). ${ }^{4}$

Locke claimed to have decided to insert a point-by-point refutation of Herbert's position only at a late stage in the writing process. And indeed, the final sections of the third chapter, where this discussion is to be found, do give the impression of being a sort of appendix. ${ }^{5}$ It is more than reasonable that Locke should have had to go back to Herbert's book for the details of his account. ${ }^{6}$ Locke, however,

\footnotetext{
${ }^{2}$ John Locke, An Essay concerning Human understanding, I.ii.1, ed. by Peter H. Nidditch, Oxford: Clarendon, 1975, p. 48 (emphasis in the original).

${ }^{3}$ On the widespread acceptance of innatism and the of argument from universal consent in seventeenth-century England, see John W. Yolton, John Locke and the Way of Ideas, Oxford: Clarendon Press, 1956, pp. 26-71; Robert L. Armstrong, "Cambridge Platonists and Locke on Innate Ideas," Journal of the History of Ideas 30/2 (1969), pp. 187-2O2; Jasper Reid, "The Common Consent Argument from Herbert to Hume," Journal of the History of Philosophy 53/3 (2015), pp. 401-433.

${ }^{4}$ In Essay I.iii.5, Nidditch, p. 68 Locke refers to the "Hobbist," but only in passing and with the intention to signal the variety of views in moral philosophy.

${ }^{5}$ Essay I.iii.15-27, Nidditch, pp. 77-84: "When I had writ this, being informed, that my lord Herbert had, in his Book de Veritate, assigned these innate Principles, I presently consulted him, hoping to find, in a man of so great parts, something that might satisfy me in this point, and put an end to my Enquiry." Locke consulted the posthumous edition of 1656, an illicit English printing (or a Dutch pirate) based on the third 1645 authorized edition, which was in turn a reprint of the 1633 London official edition. See below for a few differences between the 1633 and the 1645 edition.

${ }^{6}$ Herbert of Cherbury, De Veritate, prout distinguitur a revelatione, a verisimili, a possibili, \& a falso, London, 1633, pp. 6o-63. Herbert of Cherbury, De la Verité, en tant que elle est distincte de la Revelation, du Vray-semblable, du Possible \& du Faux, trans.
} 
had certainly already been acquainted with Herbert's main theses for some decades by this time: he had indeed been musing on the theory of universal consent since at least the early 166os, and he had already criticized Herbert by name in the second draft of the Essay (dated 1671). ${ }^{7}$ Yet, Locke did not want his readers to be misled into thinking that the position he was attacking was Herbert's and Herbert's alone. The polemical target that Locke appears to have set for himself was wider, and much more ambitious. Most interpreters have actually read the arguments of the Essay as intended to refute the philosophy of the chief early modern champion of innatism (someone even more important in this regard than Lord Herbert).

Whether and to what extent the arguments of the Essay are actually effective against Descartes' views is a much-debated topic in present-day scholarship. More and more scholars, however, have argued that Locke's supposed criticism of the Meditationes goes far wide of the mark, or is at least nonconclusive. In this paper I show that the anti-innatist arguments worked out by Locke against Herbert are ineffective against Descartes for the simple reason that Descartes himself had elaborated his theory of innate ideas in explicit opposition to Herbert's. Contrary to what has been claimed (to mention just the most outstanding instance) in a recent and otherwise well-informed article, it is simply not true that Descartes "simply ignored" Herbert's argument ex consensu omnium. ${ }^{8}$ As a matter of fact, Descartes appears to have been among the very first to criticize Herbert of Cherbury for taking universal consent as a criterion of innateness —or, even more basically, of truth. Descartes did agree with Locke on this one point, despite all the differences in their theories of ideas. ${ }^{9}$ However, whereas Locke thought that disproving Herbert's theory would refute innatism in general, Descartes believed that the

\footnotetext{
by Marin Mersenne, Paris, 1639, pp. 8o-84. Herbert of Cherbury, De Veritate, trans. by Meyrick H. Carré, Bristol: Arrowsmith, 1937, pp. 139-142. (Hereafter, respectively, "DV", "Mersenne" and "Carré”).

${ }^{7}$ See, respectively, John Locke, Essays on the Law of Nature and Associated Writings, ed. W. von Leyden, Oxford: Oxford University Press, 1954, Essay V: An lex naturce cognosci potest ex hominum consensu? Negatur, pp. 16o-179. John Locke, Drafts for the Essay Concerning Human Understanding, eds. Peter H. Nidditch and G. A. J. Rogers, Oxford: Clarendon Press, 1990; Draft $B \S 6$, pp. 111-114.

${ }^{8}$ Reid, “Common Consent," p. 403.

${ }^{9}$ The agreement between Descartes and Locke that innateness neither implies universal consent, nor vice versa, has already been noted by Daniel E. Flage and Clarence A. Bonnen, "Descartes and the Epistemology of Innate Ideas," History of Philosophy Quarterly 9/1 (1992), p. 33 n. 15; later also in Iid., Descartes and Method: A Search for a Method in the Meditations, London: Routledge, 1999, p. 51 n. 9. Antony Kenny, A New History of Western Philosophy, Oxford: Oxford University Press, 2010, p. 6oo. This paper is meant to explain the deep reasons-both historical and theoretical-behind this apparently random agreement.
} 
understanding of innateness put forward in the Meditations could succeed where Herbert had failed. This paper also argues that the first inkling of how to draw that distinction between factitious, innate and adventitious ideas, on which so great a portion of the Meditationes rests, arose in Descartes' mind in the course and context of his critical confrontation with Herbert. The paper is intended to show how, besides being of great significance in its own right, the study of Descartes' and Locke's readings of Herbert of Cherbury sheds a great light on the general seventeenth-century debate about innatism, and allows us to reconsider with fresh eyes one of the most vexed issues in early modern philosophy.

\section{Unica veritatis norma: Herbert of Cherbury on Universal Consent}

After brief mention of his aristocratic titles, the epitaph inscribed on the gravestone of Edward Herbert (1582-1648), $1^{\text {st }}$ Baron Herbert of Cherbury—or "Chirbury" — simply identifies him as "the author of the book, entitled On Truth." Indeed, the writing and rewriting of this treatise had kept Herbert busy for over twenty years. Its three editions-Paris 1624; London 1633; London 1645-mark as many turning points in Herbert's life: from the end of his ambassadorial mission to France, where he established lifelong connections with the Paris intellectual milieu (above all with Mersenne and Gassendi) up to his surrender to the Parliamentary forces during the Civil War. ${ }^{10}$

As the full title of the work makes clear-De Veritate, prout distinguitur a revelatione, a verisimili, a possibili, et a falso - the primary goal of Herbert's main philosophical treatise was to provide a definition and theory of truth both in itself and in its distinction from revealed truth, from second-rate forms of rational belief ("the probable and the possible"), and from downright falsity. Truth is defined by Herbert as "the conformity of the faculties with their objects," by contrast with the received definition thereof as the correspondence between the object and the related mental concept. Herbert is thus

\footnotetext{
${ }^{10}$ For an overall profile of Herbert's life and thought see, besides the classical and monumental Mario M. Rossi, La vita, le opere, i tempi di Edoardo Herbert of Chirbury, Florence: Sansoni, 1947; Charles de Rémusat, Lord Herbert de Cherbury: Sa vie et ses ceuvres ou les origines de la philosophie du sens common et de la théologie naturelle en Angleterre, Paris: Didier, 1874; Roland D. Bedford, The Defence of Truth: Herbert of Cherbury and the Seventeenth Century, Manchester: Manchester University Press, 1979; Eugene D. Hill, Lord Herbert of Cherbury, Boston: Twayne, 1987; Clemens Stroppel, Edward Herbert of Cherbury: Wahrheit-Religion-Freiheit, Tübingen-Basel: Francke, 200o; Sarah Hutton, British Philosophy in the SeventeenthCentury, Oxford: Oxford University Press, 2015, pp. 103-13.
} 
naturally led to expound upon the nature and classification of these "faculties" of the mind." A long section of the work is thus devoted to teaching how a mental faculty is "brought into conformity" with its object - that is to say, how the former is brought to apprehend the latter properly and, as a result thereof, to attain truth. Herbert's De Veritate is indeed, among other things, a treatise on method.

In order to ascertain whether a certain item of knowledge that the thinker takes to be true is in fact so, Herbert argues that one does not however need to go through all the criteria listed in the lengthy section on method, with its painstaking (almost exasperating) distinctions between the various faculties of the mind and the associated precepts regarding how to exercise them. To determine whether something is true, writes Herbert, it is enough to establish whether all human beings agree upon that one notion. Herbert states as explicitly that, in his view, universal consent is "the supreme" and indeed "the sole test of truth,"12 insisting that "there is no other way by which the truths of Common Notions can be ascertained. ${ }^{13}$ Although devoted to the topic of truth in general, Herbert's treatise is in fact mostly focused on one particular class of truths: the so-called "common notions."14

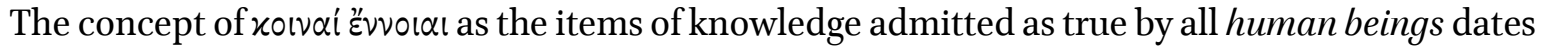
back to the Stoics, and was bequeathed to Latin medieval and early modern thinkers by Boethius. ${ }^{15}$ Herbert never took the trouble to systematically enumerate these "common notions", but the remarks scattered throughout his treatise make it clear that he had in mind a quite long, and extremely heterogeneous list thereof. Herbert's key instances of common notions were the principle of noncontradiction and general metaphysical statements such as "every natural agent is active for some end" or "that there is order, degree, change in things", as well as the claim which opens his work and guides

\footnotetext{
${ }^{11}$ On Herbert's understanding of the opposition between his definition of truth and the standard one, see DV, pp. 4-6; Mersenne, pp. 5-8; Carré, pp. 78-81.

${ }^{12}$ DV, pp. 39-40: "summa igitur veritatis norma, erit consensus universalis [...] unicam veritatis normam... facimus consensum istum universalem;" Mersenne, pp. 51-3; Carré, pp. 117-8* (the asterisk after the page number indicates that the translation has been modified). Needless to say, Herbert is considering here only non-factual truths (in necessarijs).

${ }^{13}$ DV, p. 43; Mersenne, pp. 57-8; Carré, p. 121.

${ }^{14}$ DV, p. 52: "totus liber de notitjis communibus imprimis agit;" Mersenne, p. 69; Carré, p. 131.

${ }^{15}$ Cf. Boethius, De Hebdomadibus I: "Communis animi conceptio est enuntiatio quam quisque probat auditam. Harum duplex modus est. Nam una ita communis est ut omnium sit hominum, ueluti si hanc proponas: Si duobus cequalibus cequalia auferas, quce relinquantur cequalia esse, nullus id intellegens neget. Alia uero est doctorum tantum..."
} 
all its further investigations: est veritas. ${ }^{16}$ Herbert also classified as common notions other —and even more remarkable-existential claims, such as those concerning the existence of a "first cause, an intermediate cause, and a final purpose of the world. ${ }^{.17}$ Most of Herbert's notitice communes, however, were not confined to logic or metaphysics, but pertained to particular sciences. According to Herbert, disciplines such as jurisprudence and theology had their own specific "common notions." In fact, it was precisely in the latter of these two fields that Herbert believed that the theory of universal consent could make its most substantial contribution to knowledge. Herbert claimed that it was possible, by establishing which religious tenets have been universally accepted, to single out five fundamental truths on natural religion, namely, that (i) "There is a supreme being"; (ii) "This supreme being ought to be worshipped"; (iii) "The proven conformity of the faculties is, and has always been, held to be the most important part of divine worship"; (iv) "Whatever is vicious and evil ought to be expiated by repentance"; (v) "There is reward and punishment after this life". These five tenets-which he stated again and again in all of his philosophical works — constitute the core of Herbert's philosophy, and form the best known component of his doctrine, and the one that Locke felt he should address explicitly. ${ }^{18}$

Herbert worked out an entire epistemology in order to ground this doctrine of common notions, whether in their theological form or otherwise. He insisted that if one is to understand what common notions are about, it must be made clear right from the start that they are not inferred notions and indeed cannot possibly be such. According to Herbert, common notions operate as the basic principles

\footnotetext{
${ }^{16}$ See, respectively, DV, p. 55; Mersenne, p. 73; Carré, p. 133. DV, p. 8; Mersenne, p. 10: “II y a de la Vérité;" Carré, p. 126. On Herbert's polemic against skepticism see Richard H. Popkin, The History of Scepticism from Erasmus to Spinoza, Berkeley: University of California Press, 1979, pp. 151-61.

${ }^{17}$ DV, p. 48; Mersenne, p. 64; Carré, p. 126.

${ }^{18}$ The most detailed exposition of this doctrine is to be found in DV, p. 208-23; Mersenne, pp. 269-89; Carré, pp. $289-307$. The minor changes in the third and fourth article between the 1633 and the 1645 edition are not relevant to the present discussion; cf. Günter Gawlick, "Introduction" to Herbert of Cherbury, Hauptwerke, Stuttgart-Bad Cannstatt: Frommann, 1966, pp. xxxiii-xxxiv, xlvi. Herbert has long been regarded as the father of Deism and celebrated-most notably of all by Dilthey and Cassirer - as one of the first proponents of a rigorously rational approach to religious issues; cf. Wilhelm Dilthey, "Die Autonomie des Denkens, der konstruktive Rationalismus und der pantheistische Monismus nach ihrem Zusammenhang im 17. Jahrhundert," Archiv für Geschichte der Philosophie 7/1 (1894), pp. 30-40. Ernst Cassirer, "Descartes's Wahrheitsbegriff: Betrachtungen zur 3oo-Jahresfeler des Discours de la Méthode," Theoria 3 (1937), pp. 161-87. Id., "Wahrheitsbegriff und Wahrheitsproblem bei Galilei," Scientia LXII (1937), pp. 121-30 \& 185-93. For a more recent-and accurate-assessment of Herbert's position, see Richard W. Serjeantson, "Herbert of Cherbury before Deism: The Early Reception of the De Veritate," The Seventeenth Century 16 (2001), pp. 217-38.
} 
of any argument, so that it would be logically impossible to argue against them-as well as for them. ${ }^{19}$ Herbert conceived of notitice communes mainly in terms of principles rather than as concepts, although it is important to stress that he is not always consistent on this point, partly because of an intrinsic ambiguity of notitia, which in Latin simply designates "something that is known", a certain "item of knowledge", irrespective of whether this "item" is in fact a singular concept or a principle made up of many of these latter. This ambiguity is reflected in Descartes' and Locke's critique of Herbert's account-Descartes' being mostly focused on ideas, Locke's on principles-although they too occasionally waver between these two conceptions, thereby suggesting that that the divide between these two things was not, in the seventeenth century, as clear-cut as we consider it to be today. Descartes, in particular, regarded the difference between the idea of the supreme being and the proposition "there is a supreme being" (Herbert's chief example of a notitia communis) as a matter of language, rather than of logic. ${ }^{20}$

Herbert, to be sure, did not want thereby to claim that common notions derive from senseperception. Quite to the contrary, Herbert contended that common notions are so far from resulting from experience as to be in fact the conditions of possibility of any experience-or, at least, of any meaningful one: "adeò non sunt experimenta, ut nihil sine illis verè experiri queamus." ${ }^{21}$ According to Herbert, the existence not only of a system of moral values but of the very structure of experience would be simply inconceivable without these notions, because without them we would be unable "to choose

\footnotetext{
${ }^{19}$ DV, pp. 154-5; Mersenne, p. 200-1; Carré, pp. 234-5.

${ }^{20}$ Cf. To Mersenne, July 1641, CEuvres de Descartes, ed. Charles Adam and Paul Tannery, Paris: Vrin, 1964-1974 (hereafter "AT"), vol. III, p. 395; The Philosophical Writings of Descartes, ed. and trans. by John Cottingham, Robert Stoothoff, Dugald Murdoch and Antony Kenny (hereafter “CSMK"), Cambridge: Cambridge University Press, 1985-1991, vol. III, p. 186: "It is not whether ideas are expressed by terms or by propositions which makes them belong to the intellect or the imagination, as they can both be expressed in either way." To Mersenne, 22 July 1641, AT III 417; CSMK III 187: "I do not understand your question whether our ideas are expressed by a simple term. Words are human inventions, so one can always use one or several to express the same thing." The importance of Descartes' refusal to articulate a logical (as opposed to merely linguistic) distinction between terms and propositions has already been pointed out by Gewirth Alan, "Clearness and Distinctness in Descartes," Philosophy 18 (1943), pp. 23-5. By the same token, as rightly pointed out by Alison Simmons, "Cartesian Consciousness Reconsidered," Philosophers' Imprint 12/2 (2012), p. 4: "Descartes is indifferent to the distinction we now make between object thoughts and propositional thoughts (e. g., seeing a dog vs. seeing that there is a dog in the room). As far as Descartes is concerned, these are just two different linguistic ways to describe a single mental phenomenon, and they can both be used to describe either sensory/imaginative thoughts or intellectual thoughts." It should be noticed that for Descartes, as for other thinkers of the time, ideas themselves (independently of a judgment) can be credited-at least analogically-with a truth value; cf. Meditationes III, AT VII 43-4.

${ }^{21}$ DV, p. 54; Mersenne, p. 71; Carré, p. 132.
} 
not only between what is good and evil, beneficial and harmful, but also ... to distinguish truth from falsehood." ${ }^{22}$ Herbert's claim is that, regardless of how many individual things we may be capable of perceiving, we would never have been able to come up with the thought that there is an "order, degree and change in things" unless we had already possessed an understanding of these notions. ${ }^{23}$ Even more fundamentally, Herbert contends that the intellectual and moral duty to search for truth - a duty, he argues, that all human beings perceive within themselves-is not something that is imposed on them by the objects that they happen to be confronted with. Rather, this inwardly perceived duty dictates their basic attitude qua thinkers towards the world. According to Herbert, far from coming from outside the mind, all common notions (the existence of truth being one of them) must therefore be embedded from the start within the mind. That is to say, they must be innate, and constitute "that part of knowledge that nature decided to imbue us with right from the beginning" —our innata intelligentia: ${ }^{24}$

For if it had not been written in our souls that we should examine into the nature of things (and we do not derive this command from objects), and if we had not been endowed with Common Notions, to that end, we should never come to distinguish between things, or to grasp any general nature. Vacant forms, prodigies, and fearful images would pass meaninglessly and even dangerously before our minds, unless there existed in us ... a faculty by which we distinguish good from evil in the light of the notions imprinted in the mind. From where else could we have received this knowledge? ${ }^{25}$

Herbert unfortunately does not spell out the details of his innatism: one leading scholar of his work has even gone so far as to claim that Herbert presents no real arguments at all to prove that the innateness thesis holds true, but "merely recoils from the implications that might follow if it does not". ${ }^{26}$ This is certainly unfair: several pages of the De Veritate are intended precisely to show (whether they succeed

\footnotetext{
${ }^{22}$ DV, p. 28; Mersenne, p. 38; Carré, pp. 105-6.

${ }^{23}$ DV, p. 48; Mersenne, p. 64; Carré, p. 126.

${ }^{24}$ See respectively DV, p. 47; Mersenne, pp. 62-3; Carré, p. 125 and DV, p. 11; Mersenne, p. 14; Carré, pp. 89-90.

${ }^{25}$ DV, p. 28; Mersenne, pp. 37-8; Carré, p. $105^{*}$.

${ }^{26}$ Bedford, The Defence of Truth, p. 75 .
} 
in that is, of course, another issue) that only by conceiving of common notions as innate notions could it be explained why all human beings come to apprehend and to agree upon them, despite the differences in their life-experience. The above-mentioned claims that notions such as the ones of order and degree must already be present in the mind for us to be able to move beyond particular senseperceptions and structure them into one coherent set aimed at the same conclusion.

This being said, Herbert is frustratingly vague on how these arguments are meant to work, and to work together. He even mentions four other "marks" (notce sive differentice)-besides their alleged epistemological "priority", and universal acceptance — which would set aside the most basic common notions from all other mental items, but this only complicates matters even further. ${ }^{27}$ At one point Herbert even claims that "our ignorance of the manner in which these Common Notions originate" does not represent very much of a difficulty and should not deter his readers from accepting the validity of his theory. In the end, he remarks, we have no better understanding of how we come to perceive, and yet we do undoubtedly have sense-perceptions. Let us adopt the same attitude toward our intellectual intuitions, Herbert suggests. ${ }^{28}$

Herbert realized that he needed to provide at least the gist of an answer if his theory was to win approval. And, as already pointed out, he was adamant that common notions are not "conveyed" (invehi) by external objects. ${ }^{29}$ Yet, Herbert also suggested in a few passages that bodies have an essential role to play in the process by which these innate notions are grasped. For Herbert such objects "stimulate" (excitari) or "unfold" (explicentur) the common notions and thus render them perceptible..$^{30}$ Herbert said virtually nothing about how to distinguish between these two alternative contributions of

\footnotetext{
${ }^{27}$ According to Herbert, the common notions "of the first class" can be distinguished from second-rate and indeed all other notions ex prioritate, ex independentiâ, ex universalitate, ex certitudine, ex necessitate, ex modo conformationis. See DV, pp. 6o-63; Mersenne, pp. 8o-4; Carré, pp. 139-42. Locke discusses these six "Marks of the innate Principles or common Notions" one by one (Essay I.iii.15-27, Nidditch, pp. 77-84), but rightly centers his criticism on the case from universal consent. Although listed only as third, Herbert himself in these pages does indeed speak once again of common consent as the "supreme law."

${ }^{28}$ DV, p. 52; Mersenne, p. 69; Carré, p. 131.

${ }^{29}$ DV, p. 48; "neque igitur cum objectis ipsis invehi;" Mersenne, p. 63: "aportées par les objects;" Carré, p. 126.

$3^{\circ}$ DV, p. 48; Mersenne, pp. 63-4: "expliquées;" Carré, p. 126. Carré's translation of explicentur as "revealed" is highly misleading. On Herbert's Platonism and his relations with Cambridge Platonists see Rossi, La vita, le opere, i tempi, pp. $289 f f$. and Sarah Hutton, "Lord Herbert of Cherbury and the Cambridge Platonists" in Stuart Brown (ed.), British Philosophy and the Age of Enlightenment, London: Routledge, 1996, pp. 20-42.
} 
sense-experience to the formation of common notions. But it seems at least clear that he had no metaphysical criteria in mind (revolving, for example, around some constraints on body-mind causation). I think that the distinction that Herbert intended to articulate was indeed a purely epistemological one. The reason why Herbert claimed that common notions cannot be said to derive their content from sense-experience seems to be that, in his view, experience of any object whatsoever suffices for the thinker to apprehend it: "ex omni objecto elici possunt", "ex omni objecto ... conformantur." ${ }^{31}$ According to Herbert the experience of an object qua object-independently of its specific features - would indeed be enough to elicit the thought that "there is order, degree, change in things" as well as (even more remarkably) "that there is a first cause, an intermediate cause, and a final purpose of the world. ${ }^{3^{2}}$ It is easy to understand, then, how Herbert could be so sure that all human beings of every time and culture have always been aware of these innate notions, while at the same time crediting experience with a role in their apprehension. Indeed, the contribution made by senseexperience appeared so minimal that, for Herbert, it made perfect sense to pass over it in silence for the greater part of the treatise.

Responding to the Aristotelian model of the tabula rasa, Herbert claimed that the mind should therefore rather be compared to a "closed book" listing all innate truths. Far from writing on blank slates, according to Herbert external objects only trigger the opening of pages already filled in with characters. ${ }^{33}$ In the case of what he designates as the "highest" and "most common" of these notions, Herbert maintained that the pages listing them do moreover "open themselves" and "unfold" as soon as the mind is confronted with any object: some pages of the liber clausus of the mind are thus constantly

\footnotetext{
${ }^{31}$ DV, p. 48; Mersenne, p. 64: “de toutes sortes d'obiets;" Carré, p. 126.

${ }^{32}$ Ibid.

${ }^{33}$ DV, p. 54: "Apage igitur istos qui mentem nostram, tabulam rasam, sive abrasam esse predicant, quasi ab objects haberemus, ut in illa denuo agere possimus; liber igitur ut sit clausus, sese non nisi ad objecta explicans... tabula rasa non sine injuria dicitur;" Mersenne, p. 72: "un livre clos, qui ne s'ouvre qu'aux obiets." Carré, p. 132, completely misunderstands the passage, translating "we can think of the mind as a closed book, in so far as it is not open to objects" (emphasis added). Herbert remarks, without elaborating on the point, that these notions could also be "stimulated by words, or other sorts of signs" - most probably thinking of education-referring to these symbols too as objecta, alongside the class of res (here meaning "bodies"). See DV, p. 47; Mersenne, p. 62; Carré, p. 125*. Yet, from the discussion that follows it is clear that Herbert is virtually always thinking of material objects as the triggers for innate ideas. As can easily be imagined, this aspect of Herbert's philosophy captured the attention of thinkers working in the Kantian tradition, such as the already-mentioned Dilthey, "Die Autonomie des Denkens," p. 33 and Ernst Cassirer, Das Erkenntnisproblem in der Philosophie und Wissenschaft der neueren Zeit, Berlin: Bruno Cassirer, 1907, vol. II, p. 206.
} 
unsealed. Metaphors aside, "common notions" like the principle of contradiction are for Herbert constantly structuring experience-—anyone's experience—so that all persons must have always been conversant with these innate truths.

According to Herbert, these notions must be present to all human beings if they are to attain what they all crave the most: happiness. Despite all their differences in nature and scope, Herbert maintained that all common notions share one common goal: they are designed to enable human beings to survive: "common notions above all tend towards the preservation of individuals." ${ }^{34}$ Logical principles tootogether with the resulting ability to reason-seem to interest Herbert mostly insofar as they are conductive to man's well-being. In Herbert's views it was God himself who bestowed these common notions on mankind, so that they could manage to get around in the world. The faculty of apprehending the common notions should be regarded as "the immediate instrument of divine Providence," since it is only thanks to these notions that human beings are capable of acting in such a way as to secure salvation and happiness in the after-life. ${ }^{35}$ According to Herbert the five religious tenets listed above had been engraved in men's minds precisely in order to instruct how to do to achieve eternal bliss, no one excluded. Herbert opposed the ideas of election, or predestination, defended by most of his contemporaries (especially in Protestant countries). His enquires into non-Christian religions were explicitly intended to "demonstrate that Universal Providence is extended to all mankind." ${ }^{36}$ The qualification "universal," so frequent in Herbert's writings, is of course the decisive point. For Herbert, in the final analysis, universal consent was more than just one criterion by which one might single out the indisputably true religious principles among all the many dogmata of the most disparate churches.

\footnotetext{
${ }^{34}$ DV, p. 57; Mersenne, p. 75; Carré, p. 135. See also DV, p. 61: "nulla enim notitia communis non facit ad hominis conservationem."

${ }^{35}$ DV, p. 44; Mersenne, p. 59; Carré, p. 122. Herbert credited the apprehension of common notions to the so-called faculty of "natural instinct,", which he carefully distinguished from both "discursive" and "argumentative reason" (discursus, or ratio) and also from the senses_-both "internal" and "external" ones. For the time being, however, this issue can be left aside: neither Descartes' nor Locke's criticisms of Herbert's philosophy depend to any significant degree on this specific doctrine. For a detailed discussion of Herbert's overly complex system of the faculties, see Rossi, La vita, le opere, i tempi, vol. I, pp. $368-438$.

${ }^{36}$ Herbert of Cherbury, De religione gentilium, Amsterdam, 1663, p. 4, trans. by John Anthony Butler, Pagan religion, Ottawa: Dovehouse, 1996, p. 55 .
} 
For Herbert, universal consent was first of all an instance-in fact, the supreme instance-of God's Providence with regard to Mankind. ${ }^{37}$

At a time when religious wars and theological disputes were ravaging many European countries, Herbert's insistence on the harmony between the different faiths was welcomed by Protestants and Catholics alike. Intellectuals as different as Hartlib and Mersenne circulated Herbert's work as widely as they could. In 1639 Mersenne even published a translation of the work (although only anonymously: in 1634 Herbert's De Veritate had been placed on the Catholic Church's Index of forbidden books). ${ }^{8}$ Copies were sent to Campanella, to Gassendi and Peiresc, via Elias Diodati, who offers the information that the work had even been read — and praised — by Pope Urban VIII. Both Hartlib and Mersenne were nonetheless also curious as to what one further leading philosopher of the time thought of this work. To that end, towards the end of the 1630 a few copies of Herbert's treatise were finally shipped to Northern Holland.

\section{A Decisive Reading}

In the crucial months in which the Meditationes were taking shape, Descartes read Herbert's treatise at least twice: first the Latin 1633 edition, sent to him by Hartlib (via Johann Wilhelm Eding) during the Spring of 1638, then Mersenne's 1639 translation between late August and mid-October of the same year. Descartes, as is well-known, used to brag about having "leafed through" very few books in his life: in the very letter in which he thanked Mersenne for sending him the French version of the treatise, Descartes

\footnotetext{
${ }^{37}$ DV 40: “consensum istum universalem... sine providentia divinâ non instititur;” Mersenne 53; Carré 118. Herbert's doctrine of universal consent clearly lays itself open to a charge of circularity: the existence of God is in fact inferred from the (alleged) universal belief that such a being exists, but Herbert must call upon God to justify the reliability of this (once again, alleged) consent of all human beings. As far as I can see, Herbert never addressed this difficulty.

${ }^{38}$ On the authorship of the translation, see Rossi, Alle fonti del deismo e del materialismo moderno, Firenze: La Nuova Italia, 1942, I; La vita, le opere, i tempi, vol. II, pp. 531-535; Gawlick, “Introduction," pp. xxvi-xxvii. Rossi thought highly of Mersenne's translation which-as should have already been clear from the passages quoted in the previous notes-is indeed usually accurate as far as Herbert's theory on the epistemology of common notions is concerned. See nonetheless below for a crucial difference in vocabulary from the Latin original, not listed by Rossi, La vita, le opere, i tempi, vol. III, pp. 418-427 in his survey of the discrepancies between the 1633 edition and Mersenne's 1639 translation. Mersenne, however, was less faithful when it came to Herbert's religious views, distorting and omitting some passages in the light of his own agenda; see Jacqueline Lagrée, “Mersenne traducteur d'Herbert de Cherbury," Les Études philosophiques 1/2 (1994), pp. 25-40.
} 
claimed to have no time to go through it. ${ }^{39}$ Any one of Descartes' extremely rare admissions of an intellectual debt should, then, merit a study of its own. Yet, Herbert's name is virtually absent from Cartesian studies, even from the ones specifically intended to reconstruct Descartes' intellectual biography..$^{40}$ Only more recently has Desmond Clarke suggested that the reading of Herbert's treatise might have been a turning-point for Descartes' thought. ${ }^{41}$ Clarke, however, does not provide evidence to support this claim. Furthermore, he appears to be mostly thinking of Descartes' project of providing a metaphysical foundation for physics, an issue as remote as possible from Herbert's agenda.

Both in the April (or May) 1638 letter addressed to Hartlib and in the letter to Mersenne of $27^{\text {th }}$ of August 1639 Descartes claimed to have found in Herbert's treatise some "truly excellent" remarks on metaphysical issues. ${ }^{42}$ As he came to comment more specifically on the book, however, Descartes gave voice to virtually nothing but objections. Indeed, in his letter to Mersenne of $16^{\text {th }}$ of October 1639 Descartes criticized Herbert's proposal to define truth, his arguments from common consent as well as his theory of the faculties. ${ }^{43}$ Once all these theories eliminated, it is really not clear what is left of Herbert's treatise. What Descartes does not discuss, however, is as important as what he touched upon. It is worth noting that in none of his letters reviewing Herbert's treatise did Descartes ever mention innate ideas, despite their being vital for both Herbert's philosophy and his own. Although Descartes opposed Herbert's case for innatism from universal consent (his objections will be considered in due course), Herbert's rather chaotic book included several other important claims about innate ideas. These other passages could hardly have failed to capture Descartes' attention, in part precisely because they were in tension with, and independent of, Herbert's main (and, in Descartes' eyes, mistaken) argument ex consensu omnium.

After the publication of the Essais in June 1637, the question of innatism had become a pressing one for Descartes. Some readers had complained that the proof of God's existence presented in the

\footnotetext{
39 To Mersenne, 27August 1639, AT II 570-571.

${ }^{4}$ See for example Geneviève Rodis-Lewis, Descartes: Biographie, Paris: Calmann-Lévy, 1995 or Stephen Gaukroger, Descartes: An Intellectual Biography, Oxford: Clarendon Press, 1997, p. 326, who barely mentions Herbert's name. In his Vie de Monsieur Descartes, Paris 1691, vol. II, p. 15, Baillet only sums up the letters and states (very uninformatively) that "le jugement que M. Descartes en avait fait d'abord s'était trouvé assez conforme avec celui des habiles gents de Paris."

${ }^{41}$ Desmond M. Clarke, Descartes: A Biography, Cambridge: Cambridge University Press, 2006, p. 185.

${ }^{42}$ AT II 658: "peregregia" AT II 570: "fort bonnes".

${ }^{43}$ To Mersenne, 16 October 1639, AT II 596-599.
} 
Discourse was too sketchy. Descartes partly excused himself by explaining that the rigorous proof of God's existence would have first required him to go into detail about the arguments of the Skeptics, arguments he believed were not suitable for inclusion in a work written in the vernacular. ${ }^{44}$ Descartes announced that he would have presented his full argument in Latin. His original project was a translation of the Essais (Discourse included) followed by his replies to some of the objections received, together with a new proof of God's existence. ${ }^{45}$ In May 1639, Descartes was still collecting materials with the intention of publishing the volume in the summer, but the project was eventually superseded by the Meditationes, whose manuscript was completed by the spring of the following year. ${ }^{46}$

In this Latin work, Descartes eventually resolved to set forth the most devastating skeptical doubts he could think of, with the intention of establishing as firmly as possible: the existence of the thinking I; the existence of God; the real distinction between mind and body; and the existence of the external world. Whereas the first three theses can be traced back to the Discourse, the last point represents an important element of novelty in Descartes' metaphysics. In 1637 Descartes had claimed that one can only be "morally certain" that bodies exist, as opposed to the higher-the highest possible-degree of "metaphysical certainty" attained by the proof that there is a supremely perfect being. ${ }^{47}$ Evidently unsatisfied with this conclusion, between 1638 and 1640 Descartes started to look for an argument for the existence of bodies which could compete for certainty with the remaining propositions of his metaphysics.

The specifics of the 1640 argument are not relevant to the present essay. Suffice it to say that the proof of the Meditationes is ultimately based on the concept of "adventitious ideas." ${ }^{48}$ This is indirectly confirmed by a comparison with the Discourse, which still lacked the notion of "adventitious" (as well as of "factitious") ideas, despite all its claims that "it is certain that the ideas of God and of the soul have

\footnotetext{
${ }^{44}$ Cf. To Vatier, 22 February 1638, AT I 56o. Meditationes, Prcefatio, AT VII 7-8.

${ }^{45}$ Cf. To Huygens, 9 March 1638, AT II 661. On this editorial project see Corinna Vermeulen, "Introduction" to René Descartes, Specimina philosophice, Utrecht: Zeno, 2007, pp. 2-8.

${ }^{46}$ Cf. Descartes to Huygens, 6 May 1639, AT II 677-8. To Regius and Æmilius, 24 May 1640, AT III 63-70.

${ }^{47}$ Discours IV, AT VI 37-8. Here Descartes only states that, to demonstrate that the external world exists, one must already have proven that this is the case for God. No proof, however, of this claim-nor of the former point-is offered.

${ }^{48}$ For a detailed discussion of Descartes' argument see Lew Newman, "Descartes on Unknown Faculties and Our Knowledge of the External World," The Philosophical Review 103 (1994), pp. 489-531.
} 
never been in the senses." ${ }^{19}$ The distinction between factitious, innate and adventitious ideas represents one of the most important achievements of Descartes' philosophy between 1638 and 1640.

A good portion of the Meditationes was accordingly devoted to establishing this classification. Leaving aside for the time being the case of factitious ideas and the subtleties of Descartes' argument, it suffices to point out here that Descartes established this key opposition between innate and adventitious ideas based on whether or not the thinker is able to modify "at will" (ad arbitrium) the idea's occurrence in the timeline of her thoughts. From the fact that different classes of ideas were differently modifiable in this regard, Descartes inferred that they had different origins: some from within, and some other from without the mind. Descartes characterized from the beginning adventitious ideas as the ones that

I know from experience that do not depend on my will, and hence do not depend simply on me ... For example, in this moment I feel the heat whether I want to or not (ut jam, sive velim, sive nolim), and this is why I think that this sensation, or idea, of heat comes to me from something other than myself-namely, from the heat of the fire by which I am sitting. ${ }^{50}$

"For I found", he will write later in the text, that ideas of this sort "come to me without my consent" (absque ullo meo consensu mihi advenire), from which Descartes was finally to conclude that they must come from outside the mind. ${ }^{11}$ The point becomes even clearer when Descartes turns to describe innate ideas by contrasting them with the other classes in his taxonomy. In order to establish that the notion of a supremely perfect being is somehow "inborn in the mind", Descartes argues that it suffices to note that the idea of God "has never come to me unexpectedly (nec unquam non expectanti mihi advenit), as usually happens with the ideas of things that are perceivable by the senses. ${ }^{n 5^{2}}$ According to Descartes,

\footnotetext{
${ }^{49} \mathrm{Ibid}$. Although the term "innate" is absent from the Discourse, the concept certainly is not. To the best of my knowledge the very first extant text of Descartes in which ideas themselves are qualified as "innate" is Meditationes III, AT VII 37.

${ }^{50}$ Meditationes III, AT VII 38; CSMK II 26 .

${ }^{51}$ Meditationes VI, AT VII 75; CSMK II 52.

${ }^{52}$ Meditationes III, AT VII 51; CSMK II $35^{*}$. Moreover, in Descartes' view the fact that "I plainly cannot either take away anything from it or add anything" to its representative content would also prove that this notion "has not been made by
} 
it is precisely because such notions are present to the mind right from the outset (in a sense to be spelled out in what follows) that the thinker is free to think them whenever she wants-and, accordingly, to decide whether to think them or not. In this sense, Descartes writes, innate notions can be said to be "thought of at will" (ad arbitrium cogitentur)..$^{53}$ The Meditationes' proof that God and the external world exist ultimately hinges on the notion that the idea of God is innate whereas the ideas of bodies are adventitious, a claim — in turn — that Descartes thinks to have established by virtue of the fact that I am not forced to think of the former notion at any given time "whether I want to or not" (sive velim, sive nolim), whereas this is precisely what happens to be the case as far as the ideas of bodies are

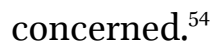

I think that Descartes' idea of classifying ideas according to whether the thinker can (or cannot) freely determine the idea's place in her stream of thoughts might have come from Herbert's De veritate. In the opening pages of his treatise, Herbert explained that one of the goals of the work was precisely to distinguish between what, in the cognitive process, is adventitium \& peregrinum and what is connatum, \& à natura dictante ortum..$^{55}$ The opposition between what is "foreign" to the mind-this being here the meaning of peregrinum-and what is "connate" is a leitmotif of the work. Just a few pages later Herbert did indeed explicitly contrast the notitice in nobis à natura insitce with the notitice adventitice \& peregrince..$^{6}$

Herbert most probably took these terms from Bacon, who had already spoken of the "native and the adventitious idols of the mind" in De Dignitate et Augmentis Scientiarum, a work published just one

me" - that is to say, that it is not factitious. Descartes concludes, therefore, that the "the only remaining alternative is that the idea of God is innate in me, just as the idea of myself is innate in me" (ibid.).

${ }^{53}$ Meditationes V, AT VII 64; CSMK II 44-5*.

${ }^{54}$ Cf. To Hyperaspistes, August 1641, AT III 428-9; CSMK III 193: "I proved the existence of material things not from the fact that we have ideas of them, but from the fact that these ideas come to us in such a way as to make us aware that they are not produced by ourselves but come from elsewhere."

${ }^{55}$ DV, p. 28; Mersenne, p. 38: “ce qui y ariue d'étranger, ou ce qu'il y a de naturels, \& de dicté par la nature;" Carré 105: "what is due to alien or accidental sources, or to factors arising from nature."

${ }^{5}$ DV, p. 54; Mersenne, p. 73: “que celles-là nous soient étrangeres;" Carré 133: "causal and external." The term "adventitious" was lost in Mersenne's-as well as in Carré's modern English-translation, but it is clear that Descartes' choice of vocabulary in the Meditationes depends on the Latin version of Herbert's treatise, if anything. Contrary to Descartes, the investigation of "adventitious ideas" was not however meant by Herbert to provide an argument for the existence of the external world, but mostly to better characterize and single out common innate notions. 
year before the first edition of the De Veritate.$^{57}$ Descartes could have done the same, since he was almost certainly acquainted with Bacon's book. It does, however, seem more plausible to suppose that it was a book that Descartes had just read and re-read between 1638 and 1639 that directly determined the vocabulary of the Meditationes, rather than a work that Descartes had probably read more than fifteen years earlier..$^{8}$ Although non-conclusive, the clues that Descartes took the term "adventitious" from Herbert are-I think-enough to make the question worth investigating. Arguably, not only the terms in which Descartes formulated his argument, but also the inspiration for drawing the distinction between innate and adventitious ideas based on whether the thinker can exert control over these ideas came to Descartes from Herbert. ${ }^{59}$

Herbert's insistence that the ideas of the senses come to perceivers "against their will" (inviti) is already remarkable: it has already been shown how much Descartes too insists on this point in order to distinguish adventitious ideas from the innate ones. ${ }^{60}$ But it is a quite surprising passage in which Herbert qualifies his theory of common notions (almost to the point of entirely overthrowing it) to suggest even more forcefully that Descartes developed his theory of innate ideas by reflecting precisely on Herbert's De Veritate. As already pointed out, the actual agreement of all human beings about a certain set of notions is the cornerstone of Herbert's system. Yet, Herbert wanted to make room for different classes of these purported "common notions", ranging from the ones which would be "in the highest degree common", to some "less common" and "least common" notions. In the course of his treatise Herbert mostly focuses on the notitice maximè communes and says virtually nothing about the inferior classes, except that the notitice minimè communes are often "hindered by prejudices" and, consequently, only seldom apprehended. ${ }^{61}$ This puts pressure on Herbert's argument ex consensu omnium. As far as the third-rate "common" notions are concerned, Herbert is forced to claim that

\footnotetext{
${ }^{57}$ Cf. Francis Bacon, De Dignitate et Augmentis Scientiarum, London 1623, V 4: "Doctrinam, quam Elenchos Magnos, sive de Idolis animi humani nativis et adventitiis appellabimus;" Francis Bacon, The Works, eds. J. Spedding, R. L. Ellis and D. D. Heath, London: Spottiswoode, 1857-1874, vol. I, p. 646.

${ }^{58}$ The same argument would lead to favor Herbert over Scholastic textbooks (possibly) employing the same terms, given the fact that Descartes had consulted most of them in his college days.

${ }^{59}$ By contrast, the thinker's capacity to freely determine the stream of her thoughts plays no role in Bacon's distinction between the "native and the adventitious idols of the mind", thereby strengthening the hypothesis that these terms and the corresponding notions came to Descartes from the De Veritate rather from the De Augmentis.

${ }^{60}$ DV 52; Mersenne 69: "malgré vous;" Carré 131.

${ }^{61}$ DV 48; Mersenne 64; Carré 126.
} 
universal consent is not a state of affairs we can already rely upon, but only an optimal condition to be achieved, a sort of regulative ideal of man's search after truth:

I do not call these [third-rate] notions "common" because they are unfolded in all human being whether they want or not (velint, nolint). They are termed "common" because they would be so but for the fact that we prevent them entering our minds. ${ }^{62}$

The soon-to-be-author of the Meditationes could only approve of Herbert's insistence that prejudices prevent some people from grasping certain intellectual truths, so that an active effort is required of the thinker to bring these truths to light. Herbert's related proposal to distinguish between different classes of notions based on whether thinkers might, or might not, think them "at will" immediately set in motion Descartes' thoughts. At the time he was looking precisely for criteria which could serve to classify mental items from the first-person perspective. ${ }^{63}$ Herbert's remarks that the ideas of external bodies come to thinkers "whether they want it or not" (whereas this is not the case for at least a certain class of intellectual notions) inspired Descartes to draw the distinction between adventitious and innate ideas based on the same criteria.

As for the "most common notions," Descartes had to part ways with Herbert. By qualifying the notitice minimè communes as the ones that thinkers do not entertain "whether they want or not," Herbert was clearly implying that this is the case for the other, higher classes of common notions. ${ }^{64}$ For Descartes, by contrast, the fact that the idea of God "has never come to me unexpectedly" was essential to prove this idea of God innate. ${ }^{65}$ Descartes had no problem admitting that some people-and, as a

\footnotetext{
${ }^{62}$ DV, p. 48: "neque igitur communes dicimus notitias istas, quia velint, nolint, in omni homine explicantur, sed ideò communes esse perhibemus, quia, nisi ipsi præcludamus viam, communes futuræ sunt;" Mersenne, p. 64: “bon gré, mal gré qu'on en ayt;" Carré, p. 126.

${ }^{63}$ It was in fact precisely on the basis of subjective criteria like these that Descartes was eventually to come to distinguish between "clear and distinct" and "obscure and confused perceptions", as well as between intellections, imaginings, and sense-perceptions.

${ }^{64}$ Since-as already pointed out-the perception of any objects whatsoever suffices for Herbert to make the perceiver aware of her first-rate innate notions, this conclusion appears to follow necessarily from the general epistemology of his treatise.

${ }^{65}$ Rossi, La vita, le opere, i tempi, vol. I, pp. 417 indicates Herbert's three classes of common notions to be the source of Descartes' distinction between factitious, innate and adventitious ideas. But clearly this cannot be the case: by introducing this distinction Herbert makes it clear that he regards all three classes of common notions as innate notions (as Rossi too
} 
matter of fact, quite a few of them — could pass their entire life without ever speculating on the question of a supreme being. ${ }^{66}$ According to Descartes, however, the point was quite different, namely, that, assuming someone does turn her thoughts to the idea of a supremely perfect being, she can think of this being in one way only:

Although it is not necessary that I ever light upon any thought of God, whenever I do choose to think of the first and supreme being (quoties tamen de ente primo \& summo libet cogitare) ... it is necessary that I attribute all perfections to him. ${ }^{67}$

For Descartes even this idea of a supremely perfect (and therefore necessarily existing) beingHerbert's paradigmatic instance of a notitia maximè communis - had therefore to be classified among Herbert's third-rate "least common notions", since this idea too does not come to the thinker independently of her will. All "common notions"—and, by the same token, all "innate ideas"—fall, according to Descartes, into this class. Descartes readily admitted that some innate notions happen to be grasped by more people than others, and that this is also due to intrinsic differences in the notions themselves (the people able to follow a mathematical treatise tend to become fewer and fewer as the argument grows more complicated). Still, even in the case of the most basic logical and metaphysical

admits). As I have hinted above and argued at length in Mattia Mantovani, “Descartes' Deduction of Ideas" (forthcoming), Descartes' classified ideas into these three classes according to whether the thinker is able to freely determine both the idea's place in her timeline of thoughts and its representative content, only the former, or neither of these. The distinction of ideas according to the will (which in Herbert always remains quite marginal and rhapsodic), prompted indeed Descartes to an extremely sophisticated reflection on the activity and passivity of the thinker as regards her ideas, considered both as mental states and as representations, which Descartes intended to be both systematic and exhaustive. To this end, Descartes added to the two terms of Herbert's distinction a third one, to indicate the idea "proceeding from a resolution of my will." Descartes designated them as the "factitious" ideas, a term quite common at his time-both in Latin and French-to indicate something "made up" as opposed to what is "natural;" cf. François Rabelais, Gargantua, ed. by Floyd Gray, Paris, Champion 1997, I xii. John Calvin, Christiance religionis institutio, Basel: Thomam Platteru \& Balthasarem Lasium 1536, 1.13.11. Desiderius Erasmus, Opus Epistolarum, ed. by P.S. Allen et alii, vols 1-12, Oxford: Oxford University Press, 1906-1958, Epistula 272. None of these authors draws any connection between being "factitious" and being "voluntary", as done on the other hand in the $12^{\text {th }}$ Century by Bernard of Clairvaux, who contrasts voluntaria vel factitia with necessaria et tamquam naturalia; Liber de prcecepto et dispensatione in Bernardi opera, ed. J. Leclercq and H.M. Rochais, 1963, vol. III, p. 255. It is highly unlikely that Descartes had read this work, but it is not to be excluded that some French theologians of his time still employed the term which this specific (or at least a similar) meaning. A preliminary survey of the relevant material has however led to no results. ${ }^{66}$ See for example To Hyperaspistes, August 1641, AT III AT 430.

${ }^{67}$ Meditationes V, AT VII 67; CSMK II 46-7 (emphasis added). 
principles, universal consent remained for Descartes an ideal condition that we should strive for, a state of affairs which could, hopefully, be achieved but does not necessarily have to be-and, as a matter of fact, in the present state of things, has not been:

There is no doubt that some common notions can be clearly and distinctly perceived $<$ by many people>, for otherwise they would not properly be called "common notions." But some of them do not have an equal claim to be called "common" among all people, since they are not equally perceived by everyone. ${ }^{68}$

These differences among thinkers are not, however, for Descartes to be imputed to an unequal distribution of intelligence. "Le bon sens est la chose du monde la mieux partagée," as he stated in the memorable opening of the Discourse. But, for Descartes, this provided no guarantee that all thinkers will eventually come to maintain the same beliefs. Descartes insisted that "it is not enough to have a sound mind: the main thing is to apply it properly" ${ }^{69}$ In the Regulce ad directionem ingenii, in the Discours de la méthode and in his metaphysical meditations Descartes was attempting to figure out precisely how the mind could best exert its natural cognitive powers. It comes, therefore, as no surprise that Descartes praised Herbert for his investigation into the cognitive faculties of the mind and his concern about method. In Descartes' view, Herbert's error consisted precisely in having abandoned this path of research to fall back into the centuries-old, but still ungrounded theory of universal consent:

The author takes universal consent as the rule for his truths. As for me, I have no rule for mine except the natural light, which to a certain extent conforms to that, since all men

\footnotetext{
${ }^{68}$ Principia I 5O, AT VIII-1 24; CSMK I 208* (emphases added). The terms in angle brackets, which make Descartes' point even more explicit, were added in the authorized French 1647 translation; cf. AT IX-2 46. Descartes, to be sure, did not thereby intend to deny that these notions are innate, as he made especially clear in Notce in programma, AT VIII-2 359; CSMK II 304-5: "Is it possible to imagine anything more absurd than that all innate (quæe menti nostrce insunt) common notions, arise from such motions [of the sense-organs] and cannot exist without them? I would like our author [Regius] to tell me what the corporeal motion is that is capable of forming some common notions to the effect that 'things which are equal to a third thing are equal to each other'... For all such motions are particular, whereas the common notions are universal and bear no affinity with, or relation to, the motions."

${ }^{69}$ Discours I, AT VI 1; CSMK I 111.
} 
have the same natural light, so that it seems that they should all have (ils semblent devoir tous avoir) the same notions. It is very different, though, since almost no one makes a proper use of this light. From which it follows that most people-all the ones we are acquainted with, for example — may agree, yes indeed, but upon the same error. ${ }^{70}$

In Descartes' view universal consent is so far from functioning as a criterion for innatism that it cannot even be considered an adequate means of ascertaining truth. Since all human beings are born with the same capacity to tell the true from the false, it follows however that, in principle, no one needs anyone else in order to establish whether something is the case or not. By contrast, prejudices may become so widespread that they infect the beliefs of an entire intellectual community, if not of the whole mankind - the "maladie universelle" deplored in a late letter to Chanut. ${ }^{71}$

Contrary to Herbert, Descartes believed that being confronted with a world was not enough for a thinker to apprehend innate ideas. To Herbert's comparison of the mind with a "closed book, which does not open itself but to objects," Descartes objected that "all truths known by themselves are not always portrayed in act in some part of our mind, the way several lines are contained in a book by Vergil," only waiting for some external objects to read them out loud..$^{72}$ According to Descartes, innate ideas are so far from being elicited by the sense-perception of any and every object that, on the contrary, no sensory experience at all is required for a thinker to grasp them. Descartes was crystal-clear that, in his view, we come to know inborn notions "by the power of our own native intelligence, without any sense-experience" (absque ullo sensuum experimento, ex proprii ingenii viribus) ${ }^{73}$ The apprehension of these innate notions is indeed for Descartes one of the most demanding achievements of man's

\footnotetext{
${ }^{70}$ To Mersenne, 16 October 1639, AT II 597-598; CSMK III 139*. On Descartes' concept of "natural light" see Boyle (2009), 81118, which aptly adjusts a few infelicitous statements of the classic John Morris, "Descartes' Natural Light," Journal of the History of Philosophy 11/2 (1973), pp. 169-87.

${ }^{71}$ Discours VI, AT VI 77. To Chanut, May 1648, AT V 183.

${ }^{72}$ Annotationes quas videtur D. des Cartes in sua Principia Philosophiæ scripsisse, AT XI 655 (my translation). This is a quite unfair caricature of Herbert's position, but the comparison of the rest of the note with the letter to Mersenne of 16 October 1639 proves that Descartes was thinking precisely of Herbert.

${ }^{73}$ Epistola ad Voetium, May 1643, AT VIII-2 166; CSMK III 222 (emphasis added). Descartes is here speaking of an ingenium rather than of the vis cognoscens in its purity-i.e. the intellect-precisely in order to stress that some notions are "congenital" to the disembodied mind rather than acquired through the senses; cf. Meditationes V \& Synopsis, AT VII 68 \& 16.
} 
cognitive life, and largely the result of a studious withdrawal from sense-perception. ${ }^{74}$ But since in order to grasp these notions the mind must do nothing but exert its own power of cogitation, Descartes also concluded that —at least in principle — any one of us can think any of these notions "at will" (ad arbitrium), whenever it pleases her to do so.

Struggling as he was to provide a proof of God's existence, Descartes pondered Herbert's treatise On Truth carefully, and only the more so deeply since he himself had subscribed to a version of Herbert's argument from universal consent at the time of his petit Traité de Métaphysique. ${ }^{75}$ Some ten years later, though, at the time of his main work on "first philosophy", Descartes had finally become convinced that Herbert's method could only provide (at best) a comparative ethnography of sorts. Contrary to what had been claimed by Herbert and by many others among his contemporaries, Descartes became convinced that metaphysical meditations had to remain, throughout, a rigorously solo enterprise. As the meditator makes clear right at the beginning of his journey, from now on he would have withdrawn from anybody else. Solus secedo. ${ }^{76}$

\footnotetext{
${ }^{74}$ Meditationes, Prcefatio, AT VII 9. Descartes' views on innatism are notoriously one of the most debated issues in all the enormous scholarship devoted to this philosopher, which is simply impossible to enter here. It must however at least be pointed out that many scholars have seen a tension between Descartes' view on the issue as presented in the Meditationes and the 1648 Notee in Programma, a passage of which (AT VIII-2 358) has often being read as endorsing a radical form of innatism, according to which all ideas would somehow count as inborn; see especially Peter Machmer and J. E. McGuire, Descartes's Changing Mind, Princeton: Princeton University Press, 2009. For a sustained defense of the "hyper-nativist" reading, cf. Geoffrey Gorham, "Descartes on the Innateness of All Ideas," Canadian Journal of Philosophy 32/3 (2002), pp. 355-388. The current paper is centered on Descartes' rejection of Herbert around 1639-1640, and does not therefore need to address Descartes' polemics with Regius some eight years later. This being said, I do however agree with the quite some scholars who see the Notae as largely consistent with Descartes' previous writings, as argued for example by Tad M. Schmaltz, "Review Essay: Descartes on Forms and Mechanisms, by Helen Hattab, and Descartes's Changing Mind, by Peter Machamer and J. E. McGuire," Oxford Studies in Early Modern Philosophy 6 (2012), pp. 349-372. But see already Marleen Rozemond, "Descartes on Mind-Body Interaction: What's the Problem?," Journal of the History of Philosophy 37 (1999), pp. 435-67. I present more arguments in favor of this claim in the above-mentioned "Descartes' Deduction of Ideas". It must in fact be pointed out that Descartes himself (just a few lines before the alleged profession of radical innatism) expressly mentions the ideas that "proceed from a resolution of my will" and the ones which "proceed from external objects" (AT VIII-2 358) namely, factitious and adventitious ideas-as distinct from and opposed to innate ones, exactly as he had done in the Meditationes.

${ }^{75}$ Cf. To Mersenne, 25 November 1630, AT I 182; CSMK III 29*: "The universal agreement of all populations is sufficient to maintain the Godhead against the insults of atheists."

${ }^{76}$ Meditationes I, AT VII 18 (the opening paragraph of the work). Although never mentioned in the letters to Mersenne and Hartlib, there is one more reason why Descartes could not accept Herbert's case from universal consent. According to Descartes the existence of thinkers other than the meditating I is indeed itself in need of a demonstration; for an analysis of the relevant texts-ranging from the Discourse to the famous letters to Newcastle of the mid-1640s, see Gareth B. Matthews, "Descartes and the Problem of Other Minds," in Amélie Oksenberg Rorty (ed.), Essays on Descartes's Meditations, Berkeley: University of California Press, 1986, pp. 141-51. Descartes' claim that every thinker must validate her own reason by appealing
} 


\section{Atheists, Naturals, Madmen: Universal Consent in Dispute}

If you had not grown up among educated people, but had spent your entire life alone is some desert spot, how do you know that the idea of God would have come to you? You derived this idea from reflecting of what you already knew, from books, from discussing with friends and so on, and not simply from your mind, or from an existing supreme being. So a clear proof needs to be provided that this idea could not be present within you if a supreme being did not exist .... However, the fact that the natives of Canada, the Hurons and other primitive people have no awareness of any idea of this sort seems to establish that the idea [of God] does not derive from innate notions (ab anticipatis notionibus) ${ }^{77}$

Unconvinced by the Meditationes' arguments that the idea of an infinitely perfect being could only have been implanted in the mind by the action of this infinitely perfect being itself, the intellectuals gathered around Mersenne objected that the idea of God could have equally easily been acquired by reasoning and then passed on through education. Descartes' innatism, they claimed, committed one to the implausible claim that any human being - even children who had grown up in isolation - would have known of this supremely perfect being. Reports by travelers indicated, however, that this was far from being the case: some newly-discovered populations around the world appeared indeed to have no notions of any god-like being.

In his long reply Descartes did not touch upon this last remark: in the Meditationes he had in fact already made clear enough that he was not endorsing Herbert's case from universal consent. In objecting to innatism, the Paris intellectuals wanted nonetheless to clear the ground of any arguments

to the divine maker of this reason if she is to be sure she is not the only thinking being in the world inverts, therefore, the terms of the argument propounded by Herbert, who intended to prove that there is such a supremely perfect being by appealing precisely to the universal consent of all human beings (whose existence is clearly taken by Herbert for granted). Reid speculates that it was precisely because they "felt that the existence of a non-deceiving God needed to be established before we could even start to know anything about what other people believed" that Descartes and his followers would have "ignored" Herbert's argument ex consensu omnium; Reid, "Common Consent," p. 403. Although Reid's factual statement is wrong, I think that he is right in connecting these two pieces of Descartes' and Herbert's philosophies.

77 Objectiones II, AT VII 124; CSMK II 56-7*. "From reflecting of what you already knew" renders "ex præconceptis animi meditationibus;" cf. Meditations, AT IX-1 98: "des pensées que vous avez euës auparavant." 
along Herbert's lines, well-known to most of them after Mersenne had circulated his translation. Although the case of the sylvestres homines-les hommes Sauvages in the French authorized translation — who lacked any notion of a god left Descartes' arguments unscathed, the objection is of devastating force against Herbert's. Accordingly, in the first book of the Essay, Locke drew extensively from the growing literature on non-European populations (carefully quoted by title and number of page) to disprove the claim that there are notions universally agreed upon by all mankind and, accordingly, Herbert's case for innatism..$^{78}$

Herbert was aware of this difficulty. Unfortunately, his strategy for dealing with it was not especially subtle: he simply denied outright that any population existed that no notion of a supreme being. (This is, regrettably, not the only case of Herbert' resorting to so lame a "subterfuge" — the term is Locke's). "I am aware that one author of reputation has said that in one remote region no religious practice can be observed", he admitted in the De Veritate, trying to downplay the difficulty as much as possible. ${ }^{79}$ However, just one exception was enough to refute his argument from universal consent. Herbert was relieved, therefore, to ensure his readers that "this statement has been rejected by a later writer, who pointed out that the former author was ignorant of the language of that country." Such discrediting of travel literature was a common strategy for early modern proponents of universal consent, who hoped thereby to silence all reports which contradicted this theory. ${ }^{80}$ Herbert was far from alone on this path: more than half a century later Edward Stillingfleet was again to make use of Herbert's very arguments to counter the travel reports quoted by Locke in the Essay ${ }^{81}$ In partial defense of Herbert it must be admitted that the explorers themselves were sometimes uncertain whether the populations they were confronted with worshipped any superior beings, as is especially clear from Jean de Léry's tremendously important Histoire d'un voyage faict en la terre du Brésil, autrement dite Amérique (1578). ${ }^{82}$

\footnotetext{
${ }^{78}$ See especially Essay I.iii.9, Nidditch, pp. 70-2. On Locke's expertise in the field, see Ann Talbot, "The Great Ocean of Knowledge": The Influence of Travel Literature in the Work ofJohn Locke, Leiden-Boston: Brill, 2010.

${ }^{79}$ DV 214: "nullam Religionis formulam;" Mersenne 277: "aucune sorte de religion, \& de culte divin;" Carré 295* (emphases added). Herbert was most probably thinking of José de Acosta's well-known Historia natural y moral de las Indias, Sevilla, 1590, to which he refers explicitly in his De religione gentilium.

${ }^{80}$ As brilliantly documented by Sergio Landucci, Ifilosofi e i selvaggi, Torino: Einaudi, 2014², pp. 164-219.

${ }^{81}$ Edward Stillingfleet, First Letter, London, 1697, pp. 89-9o.

${ }^{82}$ Jean de Léry, Histoire d'un voyage faict en la terre du Brésil, autrement dite Amérique, La Rochelle, 1578. English translation by Janet Whatley, The History of a Voyage to the Land of Brazil, Berkeley-Los Angeles: University of California Press, 199o. The treatise was re-edited in 1580, 1585, 1599, 16oo. On the tensions in Jean de Léry's report see Landucci, I filosofi e i selvaggi, pp.
} 
The debate on the reliability of these reports raised sound and important points about the method to be adopted in ethnographical researches, and rightfully warned against the risk involved in explorers taking their own culture as a standard according to which they could judge that of others'.

Yet, one did not need to appeal to reports about remote non-European populations in order to challenge the notion of the universal diffusion of the belief in a supreme being. Closer to home there were indeed more and more people who professed to believe in no god at all. Some of them had been, and were still being, murdered just for this reason. What, indeed, about atheists? Atheists do not exist, replied Herbert unflinchingly. "Irreligious men exist", he conceded, "and even some who appear to be atheists" ${ }^{83}$ In reality, though, they are not. According to Herbert, the only reason why some people say that they do not believe in a supreme deity is because they are appalled by the "false and shocking attributes" with which God is sometimes (but, in Herbert's eyes, mistakenly) credited. Herbert went so far as to argue that "religion is the ultimate difference of human beings", and what truly sets them off from all other animals. ${ }^{84}$ Urged to admit the existence of people who simply do not believe in any God, Herbert dismissed the objection by replying that atheists have no better reason to count as human beings - understood as "religious animals" - than "madmen and fools" according to the standard definition of man as the rational animal. ${ }^{85}$ The claim that all human beings have always believed in one God was so necessary for Herbert's argument that he was ready to exclude from mankind anyone who did not conform to his views rather than qualify (let alone abandon) the latter.

Gassendi had protested already in 1634 that the argument from universal consent could not be qualified so as to exclude anyone-neither atheists, nor madmen-from its scope, as this would destroy its pretension to universality and, thus, its alleged validity. ${ }^{86}$ In the first book of the Essay Locke expounded Gassendi's objection at length, by considering in detail the provisos usually appealed to by

182-4. Locke, at any rate, quotes Léry's Histoire in Essay I.iii.9 in support of the existence of populations with "no Acknowledgment of any God."

${ }^{83}$ DV, p. 214: "neque moramur, irreligiosos quosdam, immò \& Atheos videri posse; re ipsa enim Athei non sunt;" Mersenne, p. 277; Carré, p. 295 (emphasis added).

${ }^{84}$ Ibid.: "religio... ultima hominis differentia."

${ }^{85}$ Ibid. The expression "religious animal" is mine, but is clearly suggested by Herbert's text.

${ }^{86}$ Pierre Gassendi, Ad Librum D. Edoardi Herbertii Angli, De Veritate, Epistola, in Id., Opera omnia, Lyon 1658, vol. III pp. 4119, especially 417. This letter was translated into French in Antoine Adam (ed.), Actes du congrès du tricentenaire de Pierre Gassendi, Paris: Presses Universitaires de France, 1957, pp. 249-87. See also Gassendi to Diodati, 29 August 1634 in Correspondance de P. Marin Mersenne, ed. C. de Waard, Paris: Éditions du CNRS, 1955, vol. IV, pp. 335-41. 
the proponents of this view in order to make the argument work. Locke (like Gassendi) believed that the explorers' reports had already refuted once and for all, on empirical bases, any unqualified case for universal consent. Had he managed to prove that any qualification to this claim was untenable, Locke believed he would have succeeded in exploding once and for all any arguments along Herbert's lines.

Among the many arguments discussed in the first book of the Essay Locke paid particular attention to the claim according to which "all Men" would indeed assent to the same truths, but only "when they come to the use of Reason. ${ }^{87}$ Universal consent should, accordingly, be restricted to "reasonable" human beings alone, without taking into account "Children, Ideots, and Savages", due to the fact that people from these latter categories - referred to collectively by Locke as the "Naturals" failed, supposedly, to attain that minimal degree of rationality which would allow them to be described as rational beings in the proper sense of the term. ${ }^{88}$ But as Locke pointed out on many an occasion, any distinction of this sort between these "Naturals" and the self-proclaimed "Men of right Reason" presupposed that what was to count as "rational" had already been defined (lest falling into a circle). According to Locke, Herbert and any other defender of universal consent had however failed to set forth any such definitive criterion of the "rational". The concept of rationality defended by Herbert and indeed by virtually all the many supporters of the argument from common consent, Locke objected, was to be regarded only as an ill-conceived ad hoc expedient to exclude everybody who did not agree with them. "A very pretty way of arguing, and a short cut to Infallibility", he remarked full of scorn.

Their Argument stands thus: "The Principles which all mankind allow for true, are innate; those that Men of right Reason admit, are the Principles allowed by all mankind; we, and those of our mind, are Men of reason; therefore we agreeing, our Principles are innate. ${ }^{89}$

The criticism might sound uncharitable, but Locke had put his finger in a true difficulty of Herbert's account. In pointing out the shortcomings of inferential reasoning (discursus, or ratio) as compared to

\footnotetext{
${ }^{87}$ Essay I.ii.6-16, Nidditch, pp. 51-6 (emphasis added).

${ }^{88}$ Essay I.ii.27, Nidditch, pp. 63-4. Locke includes in the same group also "grossly illiterate" people.

${ }^{89}$ Essay I.iii.20, Nidditch, p. 8o (emphasis added).
} 
the direct apprehension of common notions, Herbert had made clear that, on his account, it was reason that had to adapt itself to what was commonly taken to be true, rather than the other way round. ${ }^{90}$ Once universal consent was assumed to be "the sole test of truth", Herbert could appeal to nothing but such a consent to identify what Locke provocatively called the "Men of right Reason". Faced with someone who did not agree on a certain principle, Herbert had, therefore, only two options available: either contend that this speaking animal was not in fact a human being or, alternatively, conclude that this alleged truth (lacking, as it did, universal consent) was not only non-innate, but altogether untrue. As insightfully pointed out by Locke, Herbert's purely descriptive theory of truth and rationality could not provide any normative standards by which his case from universal consent could be qualified as applying to "reasonable" thinkers alone.

Herbert should have realized quite early that the theory of universal consent could not be accepted without qualifications. Whereas he devoted the first 1624 edition of his main work "to the entire mankind" (universo humano generi), from 1633 onwards Herbert only appealed to "readers of upright and unimpaired judgement" and, by the same token, to "all healthy and sound men". ${ }^{91}$ Herbert is undeniably abandoning here for a moment the unmitigated theory of universal consent which he had defended throughout the treatise in all its editions. But despite the remarks on method to be found in his book On Truth and in the treatise On the Causes of Errors (appended to the 1645 edition of that work), Herbert never proved able to determine what it meant for a human being to have a "sound" understanding but via an appeal to his theory of common notions. Although aware of these difficulties, up until the very end of his life Herbert was never able to abandon his overconfidence in universal consent as the supreme, and indeed only—summa \& unica — guide in man's quest after truth.

Locke realized that most supporters of the argument from common consent would have reacted just as Herbert did, insisting that a qualified version of the argument (artfully excluding atheists,

\footnotetext{
$9^{\circ}$ See especially DV, pp. 42-3; Mersenne, p. 56; Carré, p. 120-21. Herbert often extolls intuitive knowledge at the expense of discursive reasoning, coming quite close to a form of "irrationalism;" on the topic, see Massimo Luigi Bianchi: "Conoscere immediato e conoscere discorsivo in Herbert of Cherbury e in alcuni autori della Scuola di Cambridge," in Marialuisa Baldi (ed.), Mind senior to the World: Stoicismo e origenismo nella filosofia platonica del Seicento inglese, Milano: FrancoAngeli, 1996, pp. 11-33.

${ }_{91}^{11}$ "Lectori cuivis, integri \& illibati judicii;” “Au Lecteur d'un Iugement entier \& candide” in Mersenne’s translation. DV, p. 220: "sani \& integri”; Mersenne, p. 285; Carré, p. 301*.
} 
"naturals" and madmen) was still sufficient to establish innateness. Although Locke, by and large, attacked the doctrine of universal consent on the grounds that it is empirically false, he realized that the only way to dispose of this theory was to show that, even if there could be proven to exist a universal consensus around certain notions, this consensus could still be accounted for on grounds other-and, in Locke's view, tidier-than innateness. ${ }^{92}$ To this end, in the first book of the Essay Locke presented an alternative picture of how theoretical and practical principles have gained acceptance. Regarding the latter, in particular, Locke set forth a detailed and compelling account of how adults come to regard as self-evident many of the things they have been taught when they were children, to the point of forgetting that their assent thereto to was not anything "natural" but only the result of inculcation and years-long training. ${ }^{93}$ The fact that a certain group of people (possibly the whole of mankind) agrees upon the same principles could not, therefore, be taken to establish that these principles are somehow "stamped upon the Mind of Man ... in its very first being", but only that all these people have been trained according to the same school of thought. Locke did not make explicit the most extreme consequences of the argument, but the account presented in the Essay not only challenged the inference from consent to innateness, but also called into question the even more basic (and apparently safer) inference from universal consent to truth. ${ }^{94}$ Locke's refutation of Herbert's De Veritate had reached its intended conclusion.

\footnotetext{
${ }^{92}$ Essay I.ii.3, Nidditch, p. 49: “This Argument, drawn from Universal Consent, has this misfortune in it, That if it were true in matter of Fact, that there were certain Truths, wherein all Mankind agreed, it would not prove them innate, if there can be any other way shewn, how Men may come to that Universal Agreement, in the things they do consent in; which I presume may be done."

${ }^{93}$ Cf. Essay I.iii.22-26, Nidditch, pp. 81-84.

${ }^{94}$ In his exchange with Stillingfleet Locke protested that in the Essay he had never presented any argument against the claim that (qualified) universal consent was a perfectly legitimate criterion for truth. See Works, vol. III, p. 495. But this does not mean, of course, that Locke ever supported this claim, and many subsequent thinkers—most notably of all, Bayle — made use of the Essay precisely to explode any argument along Stillingfleet's or Cudworth's lines. The issue became especially important between the late $17^{\text {th }}$ and the $18^{\text {th }}$ century: as shown by Reid, after Locke's-and, I would add, Descartes'refutation of Herbert, the supporters of the argument from common consent tended in fact to abandon the idea that universal consent established innateness, but kept on appealing to universal consent to justify the inferential move from innateness to truth.
} 


\section{Conclusions}

As the critical survey presented by Locke in the first book of the Essay suffices to attest, early modern thinkers worked out many quite different arguments in support of innatism. Locke's objections are equally diverse, and it is anything but a trivial task to pick apart the different strands of his counterarguments. Yet, even the scholars who have insisted the most on this variety of argumentative strategies agree that the case from universal consent occupies a truly extraordinary position in Locke's account, singled out as it is as "the master nativist argument" right at the beginning of the work and continuously addressed as such throughout the rest of the book ${ }^{95}$ Herbert's De Veritate was, in Locke's view, the most sophisticated and skilled presentation of this argument available at the time: the wide circulation of Herbert's work, as well as Mersenne's decision to undertake the translation of so long a treatise, attest that he was not the only one to think of Herbert's work in these terms. Refuting Herbert's De veritate meant therefore to refute an entire tradition of thought dating back to antiquity. Locke discussed it accordingly.

As this paper has tried to show, Descartes too worked out his conception of innateness by rejecting the essential core of Herbert's position. Besides pointing out that it is not de facto the case, both Descartes and Locke objected that the agreement of all-or at last of a vast number of-human beings upon certain notions did not demand these notions to be innate. And, indeed, not even true. Locke presented indeed a quite detailed alternative "sociological" account of how this consensus could come about, while Descartes called upon an "anthropological" explanation. ${ }^{96}$ Neither Descartes nor

\footnotetext{
${ }^{95}$ Samuel Rickless, “Locke's Polemic against Nativism," in Lex Newman (ed.), The Cambridge Companion to Locke's “Essay Concerning Human Understanding", Cambridge: Cambridge University Press, 2007, p. 45. The paper provides a most helpful analysis of Locke's manifold arguments against innatism. Locke's argument against dispositional accounts of innatism in light of the so-called "Awareness Principles"-according to which an idea can be meaningfully said to be in the mind only if the mind is (or at least has been) aware of it-has been much debated by scholars, also in relation to Descartes' own theory. De Rosa, in particular, has argued at length that Locke's objections are ultimately inconclusive against Descartes. For a detailed discussion of the topic see Raffaella De Rosa, "Locke's Essay, Book I: The question-begging status of the anti-nativist arguments," Philosophy and Phenomenological Research 69/1 (2004), pp. 37-64. Ead., "Locke's Critique of Innatism," in Matthew Stuart (ed.), A Companion to Locke, Chichester: Wiley-Blackwell, 2016, pp. 157-74.

${ }^{96}$ From the Meditationes onward Descartes had indeed tried to account for the diffusion of Aristotelianism-despite this latter's being, in Descartes' view, false-by appealing to the very nature of the human being: not to how human beings are educated, but to what they are. According to Descartes the experience we have of ourselves as embodied minds does indeed "naturally" prompt us to think of all objects in analogous terms, as constituted of a matter and of a non-material principle of
} 
Locke, then, could accept Hebert's doctrine that "common notions" (assuming there were any) had to be taken on trust without further examination, on account of their being the "the sacred principles which ought not be disputed", "the sacred principles which it would be a crime to argue against." ${ }^{\text {97 }}$ Both Descartes and Locke were sympathetic to Herbert's aspiration toward interreligious peace, but they thought that such a result would have been better achieved through philosophical investigations and dialogue, rather than despite them (besides their regarding philosophical enquiry as always legitimate in its own right and for its own sake). ${ }^{98}$

Locke's arguments opposing Herbert's case for innatism based on universal consent do not therefore apply to the Meditations. Locke was conversant enough with the latter work that it is reasonable to think that he was himself keenly aware of this fact. (Moreover, the letter of 16 October 1639 where Descartes criticized Herbert's De veritate had already been published by Clerselier in the second volume of the correspondence-released in 1659, and was thus easily available to Locke). Arguably, the reason why the first book of the Essay never mentions Descartes is that Locke himself had perfectly realized that the arguments against Herbert had no force against Descartes. Even more: at least as far as the argument from universal consent is concerned, Locke could well have conceived of Descartes as a forerunner rather than as a foe of his.

action: the "form", conceived in analogy to the thinking mind; cf. Responsiones VI, AT VII 440-3. See also To de Launay (?), 22 July 1641 (?), AT III 420. To Elisabeth, 21 May 1643, AT III 665-7. To Arnauld, 29 July 1648, AT V 222-3. Although Descartes denounced such a projection as illegitimate, he was crystal-clear that such an anthropomorphism (of sorts) is not the result of education. Directly to the contrary, for Descartes it is precisely because we are induced by our own nature to think of bodies in these terms that hylomorphic accounts of the kind advocated by Aristotelians came to be conceived and gained acceptance. On Descartes' psychological account of the belief in hylomorphism, see Etienne Gilson, Etudes sur le rôle de la pensée médiévale dans la formation du système cartésien, Paris: Vrin, 193o, pp. 141-9o. Daniel Garber, "Forms and Qualities in the Sixth Replies," in Id., Descartes Embodied: Reading Cartesian Philosophy through Cartesian Science, Cambridge: Cambridge University Press, 200o, pp. 257-73.

97 "Sacra illa Principia, contra quce disputare nefas". The definition recurs many a time in the treatise, see for example DV, p. 47; Mersenne, pp. 62-63; Carré, p. 125. In the third edition Herbert stated it already in the preface of the work, see p. vi (not numbered).

${ }^{9}$ Cf. Essay I.iv.24, Nidditch, p. 102: "In which posture of blind Credulity, they might be more easily governed by, and made useful to some sort of Men, who had the skill and office to Principle and guide them. Nor is it a small power it gives one Man over another, to have the Authority to be the Dictator of Principles, and Teacher of Unquestionable Truths; and to make a Man swallow that for an innate Principle, which may serve to his purpose, who teacheth them." On Locke's cultural and political concerns over innatism, see Nicholas Jolley, Locke: His Philosophical Thought, Oxford: Oxford University Press, 1999, pp. 31-2. 
The analogies between Locke and Descartes should not be pushed too far. Locke believed that the refutation of the De Veritate paved the way for a thoroughgoing rebuttal of innatism. By contrast, the reading of Herbert's treatise suggested to Descartes the distinction between innate and adventitious ideas based on whether or not thinkers can call them to mind whenever they want to. Descartes thought that this understanding of innate ideas marked a decisive improvement over Herbert's, whilst Locke remained convinced (even after having read the Meditationes) that innatism had no arguments in its favor. This is a truly crucial contrast, the importance of which it is impossible to overstate. But there is at least one point on which both Locke and Descartes concurred against most of their contemporaries: namely, that universal consent can count as a criterion neither for innatism nor for truth. At least in this case, one can suspect that Herbert would not have been very glad to see two thinkers of such different tempers and convictions finally come to an agreement.

\section{Acknowledgements}

My thanks to Vincenzo De Risi, Sarah Hutton, Mogens Laerke, Jasper Reid, the editors of this issue and the anonymous reviewers of the journal for their helpful comments to drafts of this paper.

The final stages of the research for this paper have been financed by the FWO-NWO Lead Agency Project (3H16o697): The Secretive Diffusion of the New Philosophy in the Southern Low Countries. Evidence on the Teaching of Cartesian Philosophy from Student Notebooks 1650-1750.

\section{Works Cited:}

Abbreviations

AT Charles Adam and Paul Tannery eds., CEuvres de Descartes, vols. I-XI, Paris: Vrin, 1964.

Carré Herbert of Cherbury, De Veritate - On Truth, trans. by Meyrick H. Carré, Bristol: Arrowsmith, 1937. 
CSMK The Philosophical Writings of Descartes, eds. and trans. by John Cottingham, Robert Stoothoff, Dugald Murdoch and Antony Kenny, vols. I-III, Cambridge: Cambridge University Press, 1985-1991.

DV Herbert of Cherbury, De Veritate, prout distinguitur a revelatione, a verisimili, a possibili, \& a falso, London, 1633 .

Essay John Locke, An Essay concerning Human understanding, ed. and trans. with introduction by Peter H. Nidditch, Oxford: Clarendon, 1975 .

Mersenne Herbert of Cherbury, De la Verité, en tant que elle est distincte de la Revelation, du Vraysemblable, du Possible \& du Faux, trans. Marin Mersenne, Paris, 1639.

\section{Works Cited}

Robert L. Armstrong, "Cambridge Platonists and Locke on Innate Ideas," Journal of the History of Ideas 30/2 (1969), pp. 187-202.

Francis Bacon, The Works, eds. by J. Spedding, R. L. Ellis and D. D. Heath, vols 1-14, London: Spottiswoode, $1857-1874$.

Adrien Baillet, La Vie de Monsieur Descartes, Paris, 1691. Reprint by Éditions des Malassis, 2012.

Roland D. Bedford, The Defence of Truth: Herbert of Cherbury and the Seventeenth Century, Manchester: Manchester University Press, 1979.

Massimo Luigi Bianchi: "Conoscere immediato e conoscere discorsivo in Herbert of Cherbury e in alcuni autori della Scuola di Cambridge," in Marialuisa Baldi (ed.), Mind senior to the World: Stoicismo e origenismo nella filosofia platonica del Seicento inglese, Milano: FrancoAngeli, 1996, pp. 11-33.

Deborah Boyle, Descartes on Innate Ideas, London-New York: Continuum, 2009. 
John Calvin, Christiance religionis institutio, Basel: Thomam Platteru \& Balthasarem Lasium 1536.

Ernst Cassirer, Das Erkenntnisproblem in der Philosophie und Wissenschaft der neueren Zeit, II, Berlin: Bruno Cassirer, 1907.

----, “Descartes's Wahrheitsbegriff: Betrachtungen zur 300-Jahresfeler des Discours de la Méthode," Theoria 3 (1937), pp. 161-187.

----, "Wahrheitsbegriff und Wahrheitsproblem bei Galilei," Scientia LXII (1937): 121-130 \& 185-193. Also appeared in French translation in the supplement to the volume of Scientia.

Herbert of Cherbury, De religione gentilium, Amsterdam, 1663. Pagan religion, trans. by John Anthony Butler, Ottawa: Dovehouse, 1996.

Desmond M. Clarke, Descartes: A Biography, Cambridge: Cambridge University Press, 2006.

John Cottingham, "Intentionality or Phenomenology: Descartes and the Objects of Thought," in Tim Crane and Sarah Patterson (eds.), History of the Mind-Body Problem, London: Routledge, pp. 132-148. Reprinted in Id., Cartesian Reflections: Essays on Descartes's Philosophy, Oxford: Oxford University Press, 2008, pp. 129-147.

Raffaella De Rosa, "Locke's Essay, Book I: The question-begging status of the anti-nativist arguments," Philosophy and Phenomenological Research 69/1 (2004), pp. 37-64.

----, "Locke's Critique of Innatism," in Matthew Stuart (ed.), A Companion to Locke, Chichester: Wiley-Blackwell, 2016, pp. 157-174.

Wilhelm Dilthey, "Die Autonomie des Denkens, der konstruktive Rationalismus und der pantheistische Monismus nach ihrem Zusammenhang im 17. Jahrhundert," Archiv für Geschichte der Philosophie 7/1 (1894), pp. 28-92. Also in Id., Gesammelte Schriften, II: Weltanschauung und Analyse des Menschen seit Renaissance und Reformation, Leipzig: Teubner, 1914. Reprint Stuttgart 1970.

Desiderius Erasmus, Opus Epistolarum, ed. by P.S. Allen et alii, vols 1-12, Oxford: Oxford University Press, $1906-195^{8}$.

Pierre Gassendi, Opera omnia, Lyon 1658. The 1634 letter on Herbert's De Veritate-Ad Librum D. Edoardi Herbertii Angli, De Veritate, Episola wan translated into French in Actes du congrès du tricentenaire de Pierre Gassendi, Paris: Presses Universitaires de France, 1957, pp. 249-287.

Stephen Gaukroger: Descartes: An Intellectual Biography, Oxford: Clarendon Press, 1997. 
Günter Gawlick, “Introduction” to Herbert of Cherbury, Hauptwerke, Stuttgart-Bad Cannstatt: Frommann 1966.

Daniel Garber, "Forms and Qualities in the Sixth Replies," in Id., Descartes Embodied: Reading Cartesian Philosophy through Cartesian Science, Cambridge: Cambridge University Press, 200o, pp. 257273.

Gewirth Alan, "Clearness and Distinctness in Descartes," Philosophy 18 (1943), pp. 17-36. Reprinted in Georges J. D. Moyal (ed.), René Descartes: Critical Assessments, London-New York: Routledge, 1991, vol. I, pp. $185^{-203}$.

Etienne Gilson, Etudes sur le rôle de la pensée médiévale dans la formation du système cartésien, Paris: Vrin, 1930.

Geoffrey Gorham, "Descartes on the Innateness of All Ideas," Canadian Journal of Philosophy 32/3 (2002), pp. 355-388.

Eugene D. Hill, Lord Herbert of Cherbury, Boston: Twayne, 1987.

Sarah Hutton, "Lord Herbert of Cherbury and the Cambridge Platonists," in Stuart Brown (ed.), British Philosophy and the Age of Enlightenment, London: Routledge, 1996, pp. 20-42.

----, British Philosophy in the Seventeenth-Century, Oxford: Oxford University Press, 2015.

Nicholas Jolley, Locke: His Philosophical Thought, Oxford: Oxford University Press, 1999.

Reinhardt G. Kottich, Die Lehre von den angeborenen Ideen seit Herbert von Cherbury, Berlin: Schötz, 1917.

Jacqueline Lagrée, “Mersenne traducteur d'Herbert de Cherbury," Les Études philosophiques 1/2 (1994), pp. 25-40.

Sergio Landucci, Ifilosofi e i selvaggi, Torino: Einaudi, $2014^{2}$.

Jean de Léry, Histoire d'un voyage faict en la terre du Brésil, autrement dite Amérique, La Rochelle, 1578. The History of a Voyage to the Land of Brazil, trans. by Janet Whatley, Berkeley-Los Angeles: University of California Press, 1990.

John Locke, Drafts for the Essay Concerning Human Understanding, eds. by Peter H. Nidditch and G. A. J. Rogers, Oxford: Clarendon Press, 1990. 
----, Essays on the Law of Nature and Associated Writings, ed. and trans. by W. von Leyden, Oxford: Oxford University Press, 1954.

Peter Machmer and J. E McGuire, Descartes’s Changing Mind, Princeton: Princeton University Press, 2009 .

Mattia Mantovani, “Descartes' Deduction of Ideas” (forthcoming).

Gareth B. Matthews, "Descartes and the Problem of Other Minds," in Amélie Oksenberg Rorty (ed.), Essays on Descartes's Meditations, Berkeley: University of California Press 1986, pp. 141-151.

Marin Mersenne, Correspondance, ed. C. de Waard. Paris: Éditions du CNRS, 1955.

John Morris, "Descartes' Natural Light," Journal of the History of Philosophy 11/2 (1973), pp. 169-187.

Lew Newman, "Descartes on Unknown Faculties and Our Knowledge of the External World," The Philosophical Review 103 (1994), pp. 489-531.

Klaus Oehler, "Der Consensus omnium als Kriterium der Wahrheit in der antiken Philosophie und der Patristik: Eine Studie zur Geschichte des Begriffs der Allgemeinen Meinung," Antike und Abendland 10 (1961), pp. 103-129. Reprint in Id., Antike Philosophie und byzantinisches Mittelalter: Aufsätze zur Geschichte des griechischen Denkens, München: Beck, 1969, pp. 234-271.

Richard H. Popkin, The History of Scepticism from Erasmus to Spinoza, Berkeley: University of California Press, 1979.

François Rabelais, Gargantua, ed. by Floyd Gray, Paris: Champion, 1997.

Jasper Reid, "The Common Consent Argument from Herbert to Hume," Journal of the History of Philosophy 53/3 (2015): 401-433.

Charles de Rémusat, Lord Herbert de Cherbury: Sa vie et ses ceuvres ou les origines de la philosophie du sens common et de la théologie naturelle en Angleterre, Paris: Didier, 1874.

Samuel Rickless, "Locke's Polemic against Nativism," in Lex Newman (ed.), The Cambridge Companion to Locke's "Essay Concerning Human Understanding," Cambridge: Cambridge University Press, 2007, pp. 33-66.

Geneviève Rodis-Lewis, Descartes: Biographie, Paris: Calmann-Lévy, 1995.

Mario M. Rossi, Alle fonti del deismo e del materialismo moderno, Firenze: La Nuova Italia, 1942.

----, La vita, le opere, i tempi di Edoardo Herbert of Chirbury, Florence: Sansoni, 1947. 
Marleen Rozemond, "Descartes on Mind-Body Interaction: What's the Problem?," Journal of the History of Philosophy 37 (1999), pp. 435-467.

Tad M. Schmaltz, "Review Essay: Descartes on Forms and Mechanisms, by Helen Hattab, and Descartes's Changing Mind, by Peter Machamer and J. E. McGuire," Oxford Studies in Early Modern Philosophy 6 (2012), pp. 349-372.

Richard W. Serjeantson, "Herbert of Cherbury before Deism: The Early Reception of the De Veritate," The Seventeenth Century 16 (2001), pp. 217-238.

Alison Simmons, “Cartesian Consciousness Reconsidered," Philosophers' Imprint 12/2 (2012), pp. 121.

Clemens Stroppel, Edward Herbert of Cherbury: Wahrheit - Religion - Freiheit, Tübingen-Basel: Francke, 2000.

Ann Talbot, "The Great Ocean of Knowledge": The Influence of Travel Literature in the Work of John Locke, Leiden-Boston: Brill, 2010.

Corinna Vermeulen, "Introduction" to René Descartes, Specimina philosophice, Utrecht: Zeno, 2007, pp. $1-82$.

John W. Yolton, John Locke and the Way of Ideas, Oxford: Clarendon Press, 1956. 